Check for updates

Cite this: Phys. Chem. Chem. Phys., 2017, 19, 21980

Received 28th June 2017, Accepted 25th July 2017 DOI: $10.1039 / c 7 c p 04353 h$ rsc.li/pccp

\section{Optimal hydrogen storage in sodium substituted lithium fullerides}

\author{
Mattia Gaboardi, (D)*a Chiara Milanese, ${ }^{\mathrm{b}}$ Giacomo Magnani, ${ }^{\mathrm{c}}$ Alessandro Girella, ${ }^{\mathrm{b}}$ \\ Daniele Pontiroli, ${ }^{c}$ Pacifico Cofrancesco, ${ }^{b}$ Amedeo Marini ${ }^{b}$ and Mauro Riccò (D) *c
}

\begin{abstract}
Through the substitution of $\mathrm{Li}$ with $\mathrm{Na}$ in $\mathrm{Li}_{6} \mathrm{C}_{60}$, we synthesized a series of mixed alkali cluster intercalated fullerides, $\mathrm{Na}_{x} \mathrm{Li}_{6-x} \mathrm{C}_{60}$. These compounds share lattices of $\mathrm{Na}_{6} \mathrm{C}_{60}$ and $\mathrm{Li}_{6} \mathrm{C}_{60}$ with a cubic parameter linearly dependent on $x . \mathrm{H}_{2}$ absorption and desorption were studied by means of charge/ discharge kinetic measurements and coupled calorimetric-manometric evaluation. By varying the stoichiometry, we found the best compromise among the absorption rate, temperature and amount of hydrogen for $x=0.5$ and 1. Small concentrations of Na substituted to Li significantly lower the absorption temperature of $\mathrm{Li}_{6} \mathrm{C}_{60}$, improving the hydrogenation capacity, the kinetics, and the dehydrogenation enthalpy, the latter being $43.8 \mathrm{~kJ} \mathrm{~mol}^{-1} \mathrm{H}_{2}$ for $x=1$. This study moves further toward the utilization of intercalated fullerides for hydrogen storage applications.
\end{abstract}

\section{Introduction}

Carbon nanostructures are often considered as ideal light and porous materials for the storage of gases, due to the high surface areas achievable. In particular, the interaction of hydrogen with carbon has driven the attention of researchers because of its implicit ecological and economical impact. The capability of fullerene $\mathrm{C}_{60}$ to host many electrons on its anti-bonding molecular orbitals and its propensity to interact with alkali and alkali-earth metals have stimulated the study of new structures in which hydrogen sorption might be promoted under mild conditions with high efficiencies. Many theoretical studies on metal decorated fullerenes calculated the structure of these molecules as superfulleroids (e.g. $\mathrm{Na}_{8} \mathrm{C}_{60}, \mathrm{Li}_{12} \mathrm{C}_{60}, \mathrm{Ca}_{32} \mathrm{C}_{60}$ ), with several metal ions coordinated by $\mathrm{C}_{60} \cdot{ }^{1-4} \mathrm{In}$ these particular molecules, the positive charge of alkali cations polarizes the hydrogen molecule forming a bond through an electrostatic interaction.

Anyway, all the structural investigations made so far demonstrated that, for a high grade of intercalation (i.e. 6 or more alkali metals per $\mathrm{C}_{60}$ ), structures in which the metal clusterizes in the large voids of the face centred cubic (fcc) $\mathrm{C}_{60}$ host lattice are promoted. ${ }^{5,6}$ Consequently, the theoretically predicted hydrogen absorption mechanism (i.e. electrostatic interaction) ${ }^{2}$ was not in good agreement with the observation of a spillover-like effect,

\footnotetext{
${ }^{a}$ ISIS Facility, Rutherford Appleton Laboratory, Chilton, Didcot, Oxfordshire OX11 OQX, UK. E-mail: mattia.gaboardi@stfc.ac.uk ${ }^{b}$ Pavia Hydrogen Lab, C.S.G.I. \& Department of Chemistry - Physical Chemistry Division, University of Pavia, Viale Taramelli 16, I-27100 Pavia, Italy ${ }^{c}$ Dipartimento di Scienze Matematiche, Fisiche ed Informatiche, Università degli Studi di Parma, Parco Area delle Scienze 7/A, I-43124 Parma, Italy.

E-mail: mauro.ricco@fisunipr.it
}

found in the experimental studies. ${ }^{7,8}$ In fact, in these materials the interaction of hydrogen with $\mathrm{C}_{60}$ is mediated by the presence of partly ionized alkali clusters, made of a few $\mathrm{Li}(\mathrm{Na})$ atoms (4 in $\mathrm{Li}_{6} \mathrm{C}_{60}{ }^{9}$ and $\mathrm{Na}_{6} \mathrm{C}_{60},{ }^{10}$ and $7-9$ in $\mathrm{Li}_{12} \mathrm{C}_{60}{ }^{9,11}$ and $\mathrm{Na}_{10} \mathrm{C}_{60}{ }^{5}$ ). Finally, the high occupancy of the $\mathrm{t}_{1 \mathrm{~g}}$-LUMO states of $\mathrm{C}_{60}$ by the electrons donated by metals promotes hydrogen chemisorption through the formation of $\mathrm{C}-\mathrm{H} \mathrm{sp}^{3}$ covalent bonds. ${ }^{12-14}$ Since the first study reported by Yoshida et al. ${ }^{15}$ lithium and sodium intercalated fullerides have been thoroughly investigated and it was demonstrated that they can reversibly absorb up to 5 and $3.5 \mathrm{wt}^{2} \mathrm{H}_{2}$ respectively ${ }^{12-14,16-24}$ in their pristine form and up to 6 and $3.7 \mathrm{wt} \% \mathrm{H}_{2}$ when doped with catalysts. ${ }^{25,26}$ In particular, $\mathrm{Na}_{6} \mathrm{C}_{60}$ can absorb 4 wt\% $\mathrm{H}_{2},{ }^{27}$ with reversible absorption/desorption processes between the $\mathrm{Na}_{6} \mathrm{C}_{60} \mathrm{H}_{18}$ and $\mathrm{Na}_{6} \mathrm{C}_{60} \mathrm{H}_{36}$ species at $375{ }^{\circ} \mathrm{C}\left(2.1 \mathrm{wt} \% \mathrm{H}_{2}\right.$ stored $)$, and it can be completely dehydrogenated only at $550{ }^{\circ} \mathrm{C} .{ }^{25}$ Conversely, $\mathrm{Li}_{6} \mathrm{C}_{60}$ is completely dehydrogenated above $400{ }^{\circ} \mathrm{C}$. Both lithium and sodium intercalated fullerides present advantages and disadvantages. While $\mathrm{Li}_{6} \mathrm{C}_{60}$ absorbs the highest amount of hydrogen, its stability in the hydrogenated phase $\left(\mathrm{Li}_{6} \mathrm{C}_{60} \mathrm{H}_{y}\right)$ is stronger than the hydrogenated $\mathrm{Na}_{6} \mathrm{C}_{60}$. This causes the onset temperature of desorption to be higher with respect to the parent Na intercalated phase, although the major desorption event of $\mathrm{Li}_{6} \mathrm{C}_{60} \mathrm{H}_{y}$ occurs at lower temperature than in $\mathrm{Na}_{6} \mathrm{C}_{60} \mathrm{H}_{y}{ }^{27}$ In particular, Teprovich et al. measured the activation energy $\left(E_{\mathrm{a}}\right)$ for the 2-step dehydrogenation process of $\mathrm{Na}_{6} \mathrm{C}_{60} \mathrm{H}_{y}$ and $\mathrm{Li}_{6} \mathrm{C}_{60} \mathrm{H}_{y}$ and found that the sodium intercalated phase presents two lower energy barriers $\left(E_{\mathrm{a}} \sim 119\right.$ and $\left.170 \mathrm{~kJ} \mathrm{~mol}^{-1}\right)$ compared to its lithium counterpart $\left(E_{\mathrm{a}} \sim 154\right.$ and $\left.190 \mathrm{~kJ} \mathrm{~mol}^{-1}\right)$. Another study carried out by means of coupled manometric-calorimetric measurements concluded that the overall dehydrogenation 
enthalpy value for $\mathrm{Li}_{6} \mathrm{C}_{60}$ is about $63 \mathrm{~kJ} \mathrm{~mol}^{-1} \mathrm{H}_{2} \cdot{ }^{26}$ The enthalpy of reaction for the formation of $\mathrm{C}_{60} \mathrm{H}_{36}+6 \mathrm{NaH}$ from $\mathrm{Na}_{6} \mathrm{C}_{60}$ was predicted to be $56 \mathrm{~kJ} \mathrm{~mol}^{-1} \mathrm{H}_{2}$ while in the case of $\mathrm{Na}_{10} \mathrm{C}_{60}$ it was measured to be $52 \mathrm{~kJ} \mathrm{~mol}^{-1} \mathrm{H}_{2}{ }^{23}$ The onset temperature for dehydrogenation decreases from $306{ }^{\circ} \mathrm{C}$ for $\mathrm{Li}_{6} \mathrm{C}_{60}$ to about $250{ }^{\circ} \mathrm{C}$ for $\mathrm{Na}_{6} \mathrm{C}_{60} \cdot{ }^{26,27}$ It is also worth pointing out that the addition of catalysts, useful for improving the kinetics of absorption and the maximum value of absorbed hydrogen, does not affect the enthalpy of desorption. ${ }^{26}$ This is in agreement with the role of a catalyst, present in the form either of micro- and nano-particles, in dissociating the hydrogen molecules, while the desorption of hydrogen from a $\mathrm{C}-\mathrm{H}$ bond in hydrofullerene only depends on the stability of this bond. From this point of view, the transition metal catalyst plays a non-local role (being dispersed in the carbon matrix), while the dehydrogenation of $\mathrm{C}_{60} \mathrm{H}_{y}$ is a local process (occurring within the cell). In order to improve not only the absorption kinetics, but in general the whole performance of the materials upon sorption, one has to modify the local structure (i.e. intercalated ions or clusters, the charged state of $\mathrm{C}_{60}$, etc.). Theoretical studies have also been made on hydrogenated fullerenes, showing the distorted symmetry of $\mathrm{C}_{60} \mathrm{H}_{y}$ hydrofullerenes ${ }^{28}$ and suggesting the formation of $\mathrm{Li}-\mathrm{H}$ dimeric species in hydrogenated $\mathrm{Li}_{6} \mathrm{C}_{60},{ }^{29}$ similar to what observed in the first hydrogenation step of $\mathrm{Li}_{12} \mathrm{C}_{60} \cdot{ }^{8}$

In this paper, we investigate the synthesis and the hydrogen sorption properties of the mixed phases of lithium and sodium intercalated fullerene, $\mathrm{Na}_{x} \mathrm{Li}_{6-x} \mathrm{C}_{60}$. The aim is to find the best compromise in stoichiometry to obtain interesting performance concerning the working temperatures and pressure for absorption and desorption, the gravimetric capacity, and the sorption kinetics. This was carried out by a sequential substitution of $\mathrm{Li}$ by $\mathrm{Na}$ in $\mathrm{Li}_{6} \mathrm{C}_{60}$, studying both the structural and sorption properties of the mixed phases. The presence of a small concentration of $\mathrm{Na}$ has proved to dramatically enhance the hydrogen storage performances in this class of compounds.

\section{Materials and methods}

Materials were synthesized by following a two step procedure. For a typical $\mathrm{Na}_{x} \mathrm{Li}_{6-x} \mathrm{C}_{60}$ fulleride, about $350 \mathrm{mg}$ of $\mathrm{C}_{60}(99.9 \%$, MER Corp.) were ground in an agate mortar with $x$ moles of $\mathrm{NaN}_{3}$ (99.99\%, Sigma-Aldrich). Before using, $\mathrm{NaN}_{3}$ was anhydrified by precipitation from ethanol and then treated in a dynamic high vacuum $\left(<10^{-5} \mathrm{mbar}\right)$ at $150{ }^{\circ} \mathrm{C}$ for several hours. The powder was pelletized; the pellets were placed in tantalum bags and then treated in a Pyrex ${ }^{\circledR}$ vial connected to a turbo-molecular vacuum pump. Materials were heated in a dynamic high vacuum up to $250{ }^{\circ} \mathrm{C}$ with a rate of $60{ }^{\circ} \mathrm{C} \mathrm{h}^{-1}$ and then at $450{ }^{\circ} \mathrm{C}$ at $10{ }^{\circ} \mathrm{C} \mathrm{h}^{-1}$. At this temperature, the sample was annealed for one day and finally cooled down to room temperature. The as produced $\mathrm{Na}_{x} \mathrm{C}_{60}$ was then analysed by means of X-ray diffraction to check the phase. In the second step of synthesis, $\mathrm{Na}_{x} \mathrm{C}_{60}$ samples were ground and mixed with $(6-x)$ moles of granular lithium (99\%, SigmaAldrich), previously cut in very small flakes. The mixture was milled in an agate ball mill (Fritsch Mini-Mill Pulverisette23,
$5 \mathrm{~mL}$ volume with 5 agate spheres of $10 \mathrm{~mm}$ diameter) at $30 \mathrm{~Hz}$ for $60^{\prime}$, divided into 6 rounds of $10^{\prime}$ followed by $5^{\prime}$ of break each. The obtained black powder was pelletized, placed in a tantalum bag within a Pyrex ${ }^{\circledR}$ vial, sealed in a high vacuum $\left(<10^{-5} \mathrm{mbar}\right)$, and treated at $270{ }^{\circ} \mathrm{C}$ for 2 days. Some of the $\mathrm{X}$-ray powder diffraction analyses were carried out by means of a Bruker D8 Discover instrument ( $\mathrm{Cu}-\mathrm{K}_{\alpha 1}$ radiation), working in Debye-Scherrer geometry and equipped with an area detector (GADDS). The $\mathrm{Cu}-\mathrm{K}_{\alpha 2}$ radiation was removed using a crosscoupled double Gobel mirror. Other XRD diffraction patterns were measured by means of a Xenocs Nano-inXider diffractometer, operating in wide angle X-ray scattering (WAXS). Sealed glass capillaries were filled with powder and the measurement was performed while spinning, collecting data for several hours per frame. Hydrogen absorption investigations were performed on the as prepared samples in a PCTPro-2000 manometric instrument (Setaram). About $300 \mathrm{mg}$ of the sample was heated from room temperature up to $280{ }^{\circ} \mathrm{C}$ at $5{ }^{\circ} \mathrm{C} \min ^{-1}$ under $100 \mathrm{bar}$ of hydrogen and a $10 \mathrm{~h}$ isothermal step was appended at the end of the ramp. Hydrogen desorption kinetic measurements were performed by heating the sample at $400{ }^{\circ} \mathrm{C}$ under 0.5 bar of hydrogen and appending $10 \mathrm{~h}$ of isotherm. Coupled calorimetricmanometric measurements were performed by connecting the high-pressure stainless steel cell of a Sensys high pressure DSC (Setaram) with the PCTPro equipment. About $30 \mathrm{mg}$ of the hydrogenated samples (after the first charging run) were discharged by heating from room temperature up to $450{ }^{\circ} \mathrm{C}$ at 0.5 bar of hydrogen in dynamic mode (heating rate $=5{ }^{\circ} \mathrm{C} \mathrm{min}^{-1}$ ). The uncertainty for the $\mathrm{H}_{2}$ ab/de-sorption wt $\%$ values is in the order of \pm 0.3 . All the operations of synthesis and handling of materials were carried out under air- and moisture-free conditions by working under vacuum or inside a glove box operating under light overpressure of argon $\left(\mathrm{O}_{2}\right.$ and $\mathrm{H}_{2} \mathrm{O}$ levels $\left.<1 \mathrm{ppm}\right)$.

\section{Results and discussion}

The synthesis of $\mathrm{Na}_{x} \mathrm{C}_{60}$ phases by means of the azide method produces crystalline samples, and a screening analysis of the relative X-ray diffraction patterns (not shown) confirmed the formation of the well-known fcc phases of $\mathrm{Na}_{2} \mathrm{C}_{60}$ (for $x=0.5,1$, 2 , and 3$)^{30}$ and $\mathrm{Na}_{6} \mathrm{C}_{60}$ (for $x=6$ ), ${ }^{10}$ and the monoclinic phase of $\mathrm{Na}_{4} \mathrm{C}_{60}(x=4$ and 5$) .{ }^{31}$ After the reaction with $\mathrm{Li}$, the $\mathrm{Na}_{x} \mathrm{Li}_{6-x} \mathrm{C}_{60}$ phases exhibit broadened peaks (see Fig. 1). These are in part due to the reduced size of powders and the increased disorder caused by the high-energy ball milling. Moreover, a decrease of the fcc symmetry, inducing a pseudo-fcc arrangement of fullerenes, is commonly observed in $\mathrm{Li}$ containing fullerides, leading to a small splitting of the fcc peaks that, in the case of low resolution (such as for X-ray powder diffraction), can be confused as peak broadening. For the sake of clarity, we analysed the data adopting the fcc cell of $\mathrm{C}_{60}$. The refinement of the cubic lattice parameter was carried out by means of Le Bail pattern decomposition of the diffraction patterns and demonstrated an increasing trend, according to the relative increase of $x$. For $x=6$, we found $a=14.37 \AA$, in good agreement with data 


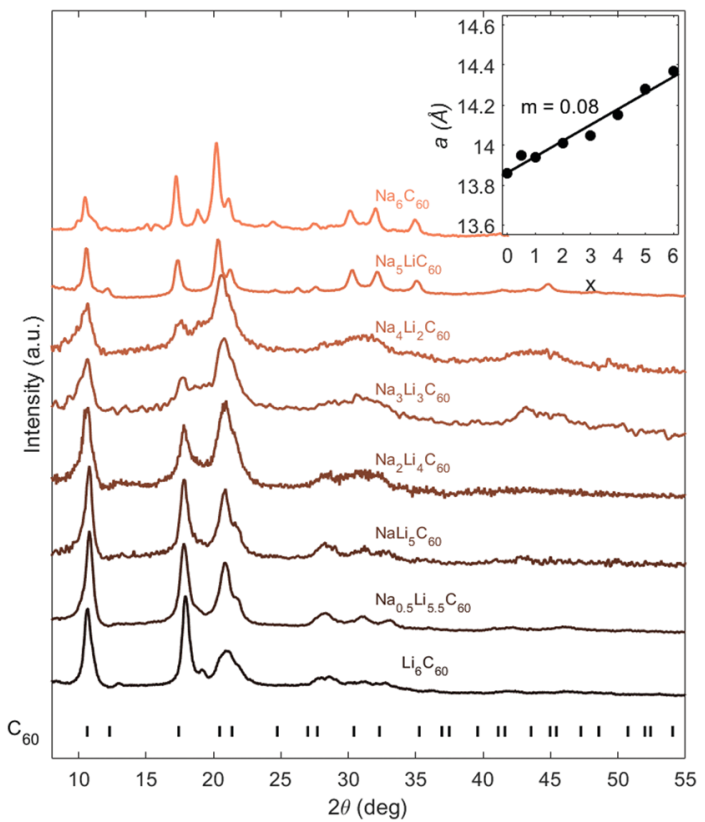

Fig. $1 \mathrm{X}$-ray powder diffraction patterns of $\mathrm{Na}_{x} \mathrm{Li}_{6-x} \mathrm{C}_{60}$. Inset: fcc lattice parameter as a function of $\mathrm{Na}$ content from $x=0$ to 6 , as obtained from Le Bail pattern decompositions.

reported in the literature $(a=14.380 \AA) .{ }^{10}$ Satellite peaks near the 111 reflection, at $\sim 10.5^{\circ}$, and the peak at $18-20^{\circ}$, between the 220 and the 311 reflections, are usually ascribed to the hexagonal distortion of the fcc lattice, occurring in stacking fault defects. ${ }^{32}$

Due to the fcc (or pseudo-fcc) arrangements of $\mathrm{C}_{60}$ molecules, the only way to fill the free space with 6 ions of $\mathrm{Na}(\mathrm{Li})$ is to allow the formation of an alkaline cluster in the central octahedral void of the cell. This cluster is tetrahedral in the case of $\mathrm{Na}_{6} \mathrm{C}_{60}{ }^{10}$ but still unknown in the novel $\mathrm{Na}_{x} \mathrm{Li}_{6-x} \mathrm{C}_{60}$ phases.

A recent solid-state static NMR study of the ${ }^{1} \mathrm{H},{ }^{7} \mathrm{Li}$, and ${ }^{23} \mathrm{Na}$ nuclei of these samples (for $x=0,1,5$, and 6 ) has revealed the dynamic nature of $\mathrm{Na}_{x} \mathrm{Li}_{6-x} \mathrm{C}_{60} \cdot{ }^{33} \mathrm{Na}$ and Li occupancies in the fcc octahedral and tetrahedral sites of $\mathrm{NaLi}_{5} \mathrm{C}_{60}$ and $\mathrm{Na}_{5} \mathrm{LiC}_{60}$ appear to be disordered at low temperature. Two ionic dynamics with distinct activation energies were attributed to intrasite (starting above $100 \mathrm{~K}$ ) and intersite (starting above $350 \mathrm{~K}$ ) motions of the two metals, with the exception of $\mathrm{Na}$ in $\mathrm{NaLi}_{5} \mathrm{C}_{60}$ that appears to be static (at least up to $350 \mathrm{~K}$ ). An in depth structural analysis by means of neutron diffraction at low temperature would be necessary to understand the nature of the clusters, although it is beyond the purpose of this work.

As well as previously reported, the addition of $\mathrm{Na}$ to $\mathrm{C}_{60}$ is known to destabilize the hydrogenation process in $\mathrm{Na}_{10} \mathrm{C}_{60}$, promoting the dissociation of hydrofullerene below $300{ }^{\circ} \mathrm{C}$, even in the presence of $100 \mathrm{bar}_{2} \cdot{ }^{13,23}$ Thus, we decided to hydrogenate the samples below this temperature. The hydrogenation was carried out at $280{ }^{\circ} \mathrm{C}$ under $100 \mathrm{bar}_{2}$. The first hydrogen absorption and desorption cycle is reported, as a function of time, in Fig. 2. The most important results on the hydrogen sorptions of $\mathrm{Na}_{x} \mathrm{Li}_{6-x} \mathrm{C}_{60}$ are reported in Table 1 .

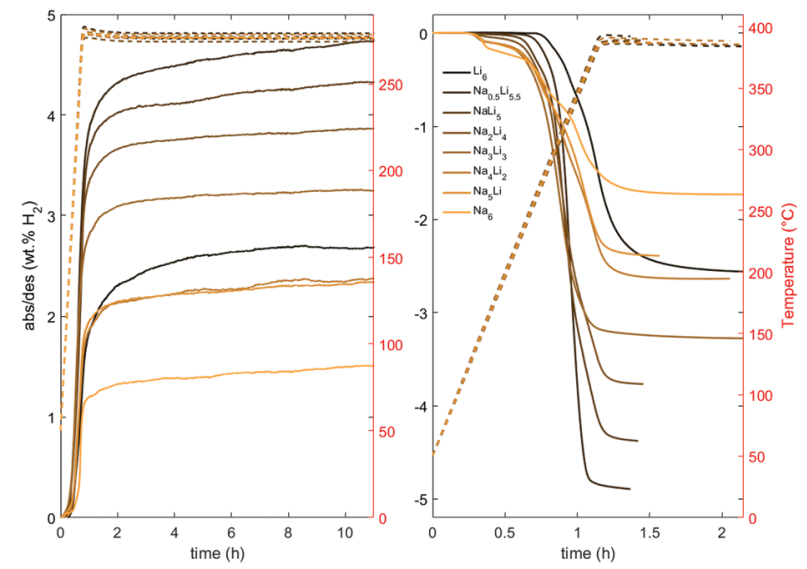

Fig. 2 Kinetic hydrogen absorption (left) and desorption curves (right) for $\mathrm{Na}_{x} \mathrm{Li}_{6-x} \mathrm{C}_{60}$ are reported as a function of time (solid lines, left $Y$-axes). The right $Y$-axes represent the temperature (dashed lines).

Table 1 Kinetic absorption and desorption parameters of $\mathrm{Na}_{x} \mathrm{Li}_{6-x} \mathrm{C}_{60}$ (absorbed $\mathrm{H}_{2}$ capacity at $280{ }^{\circ} \mathrm{C}$ and after the isotherm, onsets and rate of desorption) as established from Fig. 2, and $\Delta H_{\text {des, }}$ as calculated from DSC curves shown in Fig. 3. The temperature rate for the desorptions was $5{ }^{\circ} \mathrm{C} \mathrm{min}{ }^{-1}$. The uncertainty for the $\mathrm{H}_{2}$ ab/de-sorptions is in the order of $\pm 0.3 \mathrm{wt} \%$

\begin{tabular}{lllllll}
\hline & $\begin{array}{l}\text { Abs. at } \\
280\end{array}$ & \multicolumn{5}{c}{$\mathrm{C}$} \\
$\left(\mathrm{wt} \% \mathrm{H}_{2}\right)$ & $\begin{array}{l}\text { Max abs. Des. } \\
\left(\mathrm{wt} \% \mathrm{H}_{2}\right)\end{array}$ & $\begin{array}{l}\text { Rate of } \\
\left(\mathrm{wt} \% \mathrm{H}_{2}\right)\end{array}$ & $T_{\mathrm{on}}^{\mathrm{des}}\left({ }^{\circ} \mathrm{C}\right)$ & $\begin{array}{l}\text { abs. }\left(10^{-2}\right. \\
\mathrm{wt} \% / \mathrm{min})\end{array}$ & $\begin{array}{l}\Delta H_{\mathrm{des}} \\
\left(\mathrm{kJ} \mathrm{mol}^{-1}\right)\end{array}$ \\
\hline 0 & 1.5 & 2.7 & 2.6 & 306 & 3.9 & $61.2^{a}$ \\
0.5 & 3.4 & 4.7 & 4.9 & 293 & 7.0 & 57.6 \\
1 & 3.1 & 4.3 & 4.4 & 283 & 6.5 & 43.8 \\
2 & 3.0 & 3.9 & 3.8 & $134 ; 285$ & 5.9 & 56.1 \\
3 & 2.6 & 3.3 & 3.3 & $132 ; 273$ & 4.7 & 52 \\
4 & 1.7 & 2.4 & 2.6 & 317 & 3.3 & 69.7 \\
5 & 1.8 & 2.3 & 2.4 & $128 ; 231 ; 320$ & 3.5 & 61.0 \\
6 & 1.1 & 1.5 & 1.7 & $142 ; 295$ & 2.3 & 66.0
\end{tabular}

${ }^{a}$ Value calculated for the completely hydrogenated $\mathrm{Li}_{6} \mathrm{C}_{60}\left(100\right.$ bar $\mathrm{H}_{2}$ at $350{ }^{\circ} \mathrm{C}$ ).

The hydrogen absorption curves showed that both the gravimetric capacity and the absorption rate significantly improve for small $\mathrm{Na}$ contents and the values obtained for the mixed compounds $\mathrm{Na}_{0.5} \mathrm{Li}_{5.5} \mathrm{C}_{60}, \mathrm{NaLi}_{5} \mathrm{C}_{60}, \mathrm{Na}_{2} \mathrm{Li}_{4} \mathrm{C}_{60}$, and $\mathrm{Na}_{3} \mathrm{Li}_{3} \mathrm{C}_{60}$ are better than for $\mathrm{Li}_{6} \mathrm{C}_{60}$, testifying the catalytic-like activity of $\mathrm{Na}$ when added in small concentration to the Li-fullerite. The hydrogen sorptions were found to be reversible for all the stoichiometries, as shown by the kinetic desorptions.

The dehydrogenation calorimetric profiles recorded on the samples after the first hydrogenation run show an increase in complexity upon increasing the Na content (see Fig. 3). For $x=0$ we reported the desorption of $\mathrm{Li}_{6} \mathrm{C}_{60}$ previously hydrogenated at $350{ }^{\circ} \mathrm{C}$ and 100 bar $\mathrm{H}_{2}$ (storage capacity $5.2 \mathrm{wt} \% \mathrm{H}_{2}$ ). A sharp endothermic peak is observed, starting from about $290{ }^{\circ} \mathrm{C}$ and with maximum at $330{ }^{\circ} \mathrm{C}$, possibly formed by two main processes close in temperature, as suggested by the asymmetric shape. A similar feature is observed in $\mathrm{Na}_{0.5} \mathrm{Li}_{5.5} \mathrm{C}_{60}$, although this time the asymmetry is twisted, the variation starts at $230{ }^{\circ} \mathrm{C}$ and the maximum of the peak is shifted at $310{ }^{\circ} \mathrm{C}$. The twofold nature of the peak is better evident in $\mathrm{NaLi}_{5} \mathrm{C}_{60}$. The desorption starts at $230{ }^{\circ} \mathrm{C}$ and the main peak can be deconvoluted by two processes 


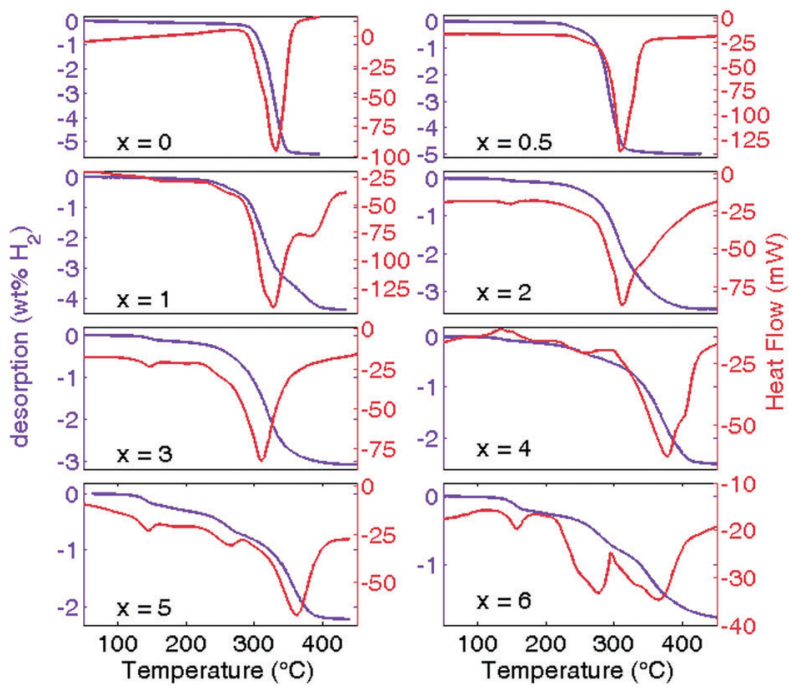

Fig. 3 Differential scanning calorimetric curves (red) and relative $\mathrm{H}_{2}$ desorption kinetics (blue) for $\mathrm{Na}_{x} \mathrm{Li}_{6-x} \mathrm{C}_{60}$ samples hydrogenated at $280{ }^{\circ} \mathrm{C}$ are reported as a function of temperature. For $x=0$, the DSC curve is reported for the sample hydrogenated at $350^{\circ} \mathrm{C}$ (see also ref. 26).

with maximum at 305 and $318{ }^{\circ} \mathrm{C}$ respectively. Moreover, a new broad peak can be observed at $\sim 380{ }^{\circ} \mathrm{C}$. By increasing the $\mathrm{Na}$ stoichiometry above 1 , two features become evident: the appearance of a small peak at around $145-160^{\circ} \mathrm{C}$ and another endothermic and broad peak at higher temperatures $\left(360-380{ }^{\circ} \mathrm{C}\right)$. Both increase in amplitude with an increase in Na stoichiometry. An exception is found for $x=4$, where the peak at $145{ }^{\circ} \mathrm{C}$ is confused with the background. All these peaks are coupled with mass loss, hence they are dehydrogenation steps. The relative hydrogen desorption enthalpies were obtained after suitable subtraction of the background and are reported in Table 1. The desorption enthalpy decreases from $66.0 \mathrm{~kJ} \mathrm{~mol}^{-1} \mathrm{H}_{2}$ for pure $\mathrm{Na}_{6} \mathrm{C}_{60}$ to $43.8 \mathrm{~kJ} \mathrm{~mol}^{-1} \mathrm{H}_{2}$ for $\mathrm{NaLi}_{5} \mathrm{C}_{60}$, a value lower than that determined by us for $\mathrm{Li}_{6} \mathrm{C}_{60}\left(61.2 \mathrm{~kJ} \mathrm{~mol}^{-1} \mathrm{H}_{2}\right)$.

An intermediate value of $57.6 \mathrm{~kJ} \mathrm{~mol}^{-1} \mathrm{H}_{2}$ was found for $x=0.5$ stoichiometry, the sample displaying the best desorption of $4.9 \mathrm{wt} \% \mathrm{H}_{2}$. Anyway, from the combined analysis of the kinetic hydrogen absorption and the coupled calorimetric/ manometric desorption curves it is evident that $\mathrm{NaLi}_{5} \mathrm{C}_{60}$ is the most promising stoichiometry in terms of kinetics and thermodynamics, important technological parameters. The desorption enthalpy of $\mathrm{NaLi}_{5} \mathrm{C}_{60}$ is $17.4 \mathrm{~kJ} \mathrm{~mol}^{-1} \mathrm{H}_{2}$ lower than in $\mathrm{Li}_{6} \mathrm{C}_{60}$. Thus, the highest rate of absorption, and the lower temperature of absorption suggest that Na plays an important role in the bulk properties of the material. The absorption of $\mathrm{NaLi}_{5} \mathrm{C}_{60}$ reaches $4.3 \mathrm{wt} \% \mathrm{H}_{2}$, for a temperature where $\mathrm{Li}_{6} \mathrm{C}_{60}$ only absorbs $2.7 \mathrm{wt} \% \mathrm{H}_{2}$, and with a kinetics comparable to samples decorated with Pd catalysts. ${ }^{26}$

The X-ray powder diffraction patterns of hydrogenated $\mathrm{Na}_{x} \mathrm{Li}_{6-x} \mathrm{C}_{60}$ are reported in Fig. 4 for $x=0,0.5,1,3$, and 5. After hydrogenation at $280{ }^{\circ} \mathrm{C}$, the fcc cell results expanded due to the increase in the volume of $\mathrm{C}_{60}$ after $\mathrm{C}-\mathrm{H}$ bond formation. In the case of $\mathrm{Li}_{6} \mathrm{C}_{60}$, the lattice evolved from fcc to bcc when hydrogenated completely at $350{ }^{\circ} \mathrm{C} .{ }^{12}$ This phase transition is

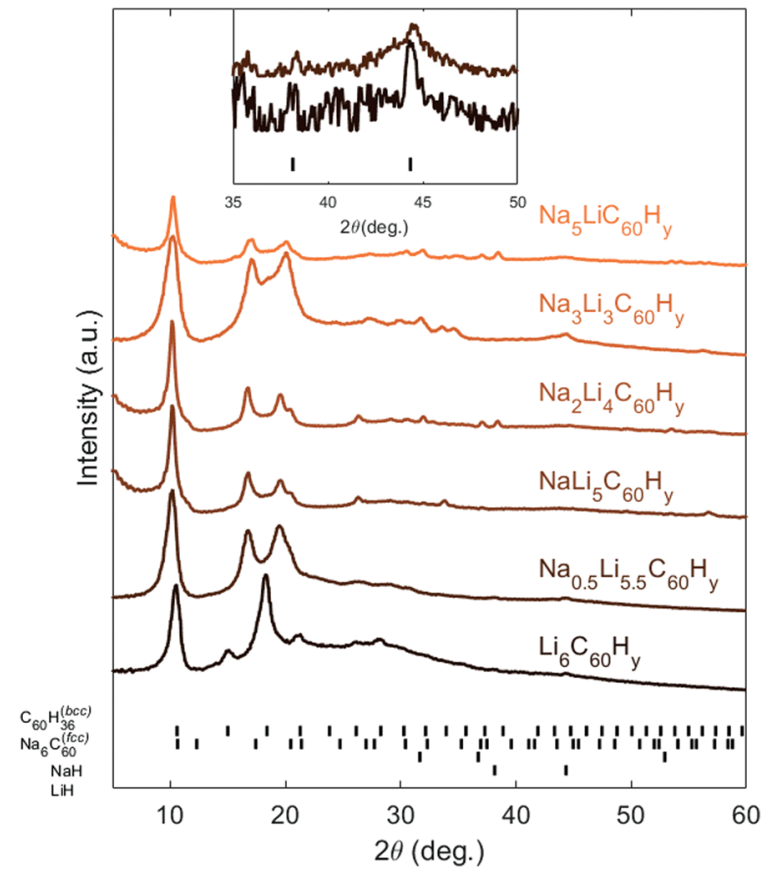

Fig. 4 X-ray powder diffraction patterns for selected $\mathrm{Na}_{x} \mathrm{~L}_{6-x} \mathrm{C}_{60}$ compounds after the first hydrogen absorption at $280{ }^{\circ} \mathrm{C}$ (100 bar). The pattern of $\mathrm{Li}_{6} \mathrm{C}_{60}$ hydrogenated at $350{ }^{\circ} \mathrm{C}$ and 100 bar $\mathrm{H}_{2}$ is reported for comparison. Inset: Zoom for hydrogenated $\mathrm{Li}_{6} \mathrm{C}_{60}$ and $\mathrm{Na}_{0.5} \mathrm{Li}_{5.5} \mathrm{C}_{60}$ diffractions showing the region of $\mathrm{LiH}$ peaks.

commonly observed in hydrogenated fullerene. ${ }^{34-37}$ Anyway, even a small substitution of $\mathrm{Li}$ with $\mathrm{Na}$ seems to be enough to overcome this structural change, which we recently recognized as a kinetics limiting process in $\mathrm{Li}_{6} \mathrm{C}_{60}{ }^{24}$ It is worth highlighting the detection of peaks at the Bragg angle expected for $\mathrm{LiH}$ in $x=0$ and 0.5 , although a quantitative estimation can not be done from XRD data, due to the unknown structure of the hydrofullerene anion and the low scattering factor of $\mathrm{Li}$ and $\mathrm{H}$. $\mathrm{LiH}$ features were not observed for $x>0.5$, but this could be due to the lower content of $\mathrm{Li}$, at the limit of detection. Curiously, the formation of $\mathrm{NaH}$, although documented in the hydrogenation of $\mathrm{Na}_{10} \mathrm{C}_{60}$, was never observed in hydrogenated $\mathrm{Na}_{x} \mathrm{Li}_{6-x} \mathrm{C}_{60}$. This suggests the fact that $\mathrm{Na}$, contrary to $\mathrm{Li}$, never segregates from the fulleride during the hydrogenation and its charge remains available for the dissociation of $\mathrm{H}_{2}$ into the hydrofullerene anion $\left(\mathrm{C}_{60} \mathrm{H}_{y}{ }^{n-}\right)$, also facilitating the desorption process.

In order to have a better understanding of the processes involved in the hydrogen desorption, we carried out the analysis of the derivative of the desorption curves. Therefore, it was possible to separate the different processes involved when varying the stoichiometry. In Fig. 5 the rates of desorption are reported as a function of time and the profile of desorption has been fit to Gaussian functions. It is possible to identify at least four main processes. An isolated process occurring at around $145{ }^{\circ} \mathrm{C}$ is appreciable only for $x>0.5$ and was already recognized in the DSC profile analysis. Moreover, three convoluted processes occurring above $200{ }^{\circ} \mathrm{C}$ were also easily detected.

The values of partial dehydrogenation, as extracted from the fits for each step, are reported, normalized, in Fig. 6. 

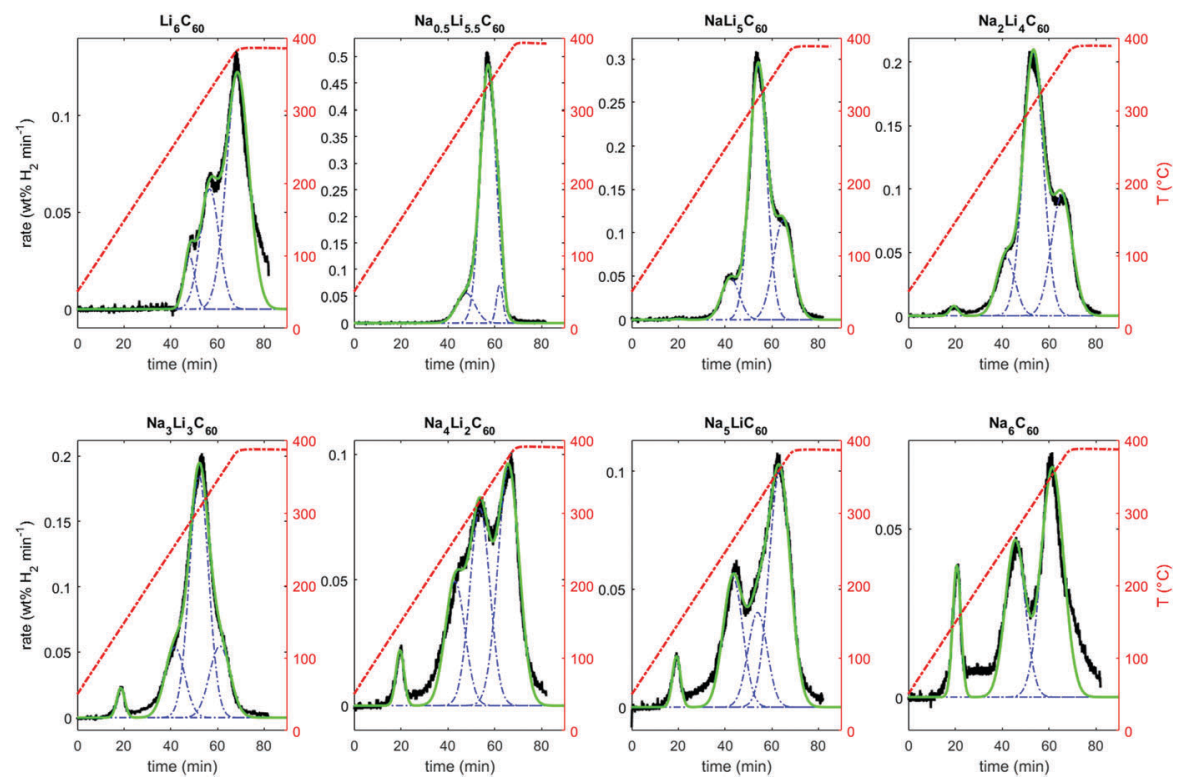

Fig. 5 Hydrogen desorption rates (black) and fit (green) according to Gaussian functions (blue) of hydrogenated $\mathrm{Na}_{x} \mathrm{Li}_{6-x} \mathrm{C}_{60}$ reported as a function of time. The temperature rate is reported on the right $Y$-axis (red dashed lines).

It is evident that the first peak of desorption, between $140-155{ }^{\circ} \mathrm{C}$, depending on $x$, is highly affected by the content of $\mathrm{Na}$, being absent for $\mathrm{Li}_{6} \mathrm{C}_{60}$ and $\mathrm{Na}_{0.5} \mathrm{Li}_{5.5} \mathrm{C}_{60}$, slightly visible in $\mathrm{NaLi}_{5} \mathrm{C}_{60}$, and progressively more consistent for $2 \leq x \leq 6$. It is worth pointing out that the percentage of desorbed hydrogen is not only dependent on the amount of hydrogen but also on the stoichiometry of the absorber. Therefore, an increasing (decreasing) $\mathrm{wt} \%$ of $\mathrm{H}_{2}$, when varying the amount of $\mathrm{Na}$ in the structure, does not necessarily correspond to the same variation in the stoichiometric content of hydrogen. For instance, assuming that the only product of hydrogenation is $\mathrm{Na}_{x} \mathrm{Li}_{6-x} \mathrm{C}_{60} \mathrm{H}_{y}$, $1 \mathrm{wt} \% \mathrm{H}_{2}$ in $\mathrm{NaLi}_{5} \mathrm{C}_{60}$ or $\mathrm{Na}_{6} \mathrm{C}_{60}$ corresponds to a different value of $y=7.8$ and 8.6 hydrogens respectively. The amount of hydrogen released in the first process is very low and varies between 0.02

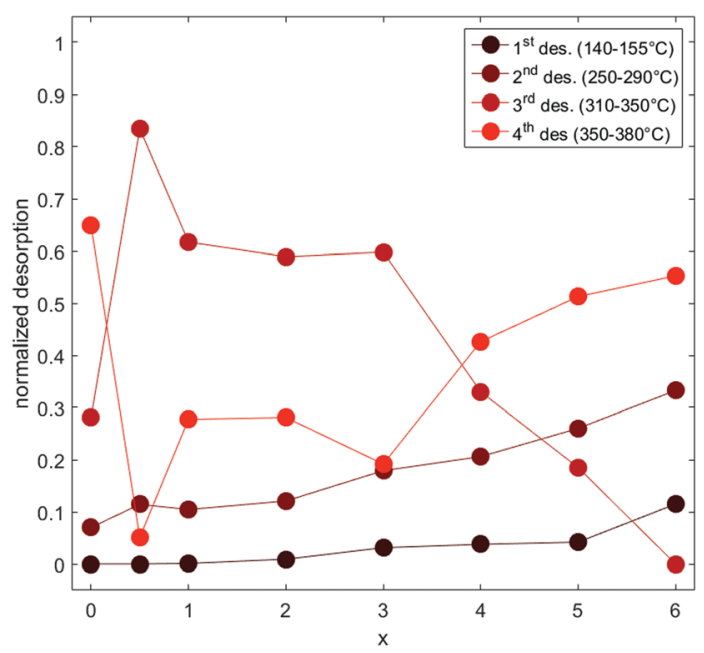

Fig. $6 \mathrm{Na}_{x} \mathrm{Li}_{6-x} \mathrm{C}_{60} \mathrm{H}_{y}$ partial desorptions reported as a function of $x$ and normalized to the maximum desorption. (for $x=1$ ) and $0.2 \mathrm{wt} \% \mathrm{H}_{2}$ (in $\mathrm{Na}_{6} \mathrm{C}_{60}$ ), corresponding to about $0-2$ hydrogen atoms per $\mathrm{C}_{60}$, while the minimum temperature for this step is found for $x=3\left(140{ }^{\circ} \mathrm{C}\right)$. The second process is visibly lower in temperature for $\mathrm{Na}$ containing samples $\left(247^{\circ} \mathrm{C}\right.$ for $x=2)$ than for $\mathrm{Li}_{6} \mathrm{C}_{60}\left(291{ }^{\circ} \mathrm{C}\right)$ and the amount of desorbed hydrogen varies from $0.3\left(\mathrm{Li}_{6} \mathrm{C}_{60}\right)$ to $0.95 \mathrm{wt} \%(x=4)$, corresponding to 2-8 hydrogen atoms per $\mathrm{C}_{60}$, depending on $x$.

The third process, occurring between 308 and $347^{\circ} \mathrm{C}$, is the most important and is dependent on $x$. In the case of $\mathrm{Li}_{6} \mathrm{C}_{60}$ it occurs at $323{ }^{\circ} \mathrm{C}$ and only $0.3 \mathrm{wt} \% \mathrm{H}_{2}$ is released (about 2 hydrogen atoms per $\mathrm{C}_{60}$ ). In the mixed phases, the maximum desorption is reached for $x=0.5$ at $330{ }^{\circ} \mathrm{C}$, corresponding to $3.3 \mathrm{wt} \% \mathrm{H}_{2}$ (about 26 hydrogen atoms per $\mathrm{C}_{60}$ ) and decreases progressively with $x$. The last process is the highest in temperature; it decreases in temperature with $x$ varying from $380{ }^{\circ} \mathrm{C}\left(\mathrm{Li}_{6} \mathrm{C}_{60}\right)$ to $350{ }^{\circ} \mathrm{C}(x=0.5)$ and for some samples it is completed during the isotherm. In the case of $\mathrm{Li}_{6} \mathrm{C}_{60}$ this is the most important process, coinciding with $2 \mathrm{wt} \% \mathrm{H}_{2}$ desorbed (about 15 hydrogen atoms). Anyway, for $x \neq 0$, the amount of desorbed hydrogen atoms ranges from 8 to 12 (depending on $x$ ), corresponding to about $0.3-1.2 \mathrm{wt} \%$ $\mathrm{H}_{2}$. The same analysis has been attempted for the absorption data. However, the peaks were not well separated and their deconvolutions led to ambiguous results.

Considering the amount of hydrogen desorbed per single step, it is possible to reconstruct the complete dehydrogenation path of $\mathrm{Na}_{x} \mathrm{Li}_{6-x} \mathrm{C}_{60}$ compounds. It was found that the hydrogenation involves the segregation of part of the metal in the form of hydride (only LiH in our case). ${ }^{14}$ Therefore, we can adopt the following general equation:

$$
\mathrm{Na}_{x} \mathrm{Li}_{6-x} \mathrm{C}_{60}+\frac{y}{2} \mathrm{H}_{2} \stackrel{(T, p)}{\Leftrightarrow} \mathrm{Na}_{x} \mathrm{Li}_{6-x-\alpha} \mathrm{C}_{60} \mathrm{H}_{y-\alpha}+\alpha \mathrm{LiH}
$$

Here $\alpha$ is the amount of lithium hydride formed after complete hydrogenation. Unfortunately, it is difficult to quantify this 
value from the XRD data, since the structure of hydrofulleride is unknown and a quantitative phase analysis via Rietveld refinement is not possible. In $\mathrm{Na}_{10} \mathrm{C}_{60}, \mathrm{Li}_{6} \mathrm{C}_{60}$, and $\mathrm{Li}_{12} \mathrm{C}_{60}$ part of the alkali metal is de-intercalated in the form of hydride during the absorption process. ${ }^{13,14,24}$ The measurement on hydrogenated $\mathrm{Na}_{x} \mathrm{Li}_{6-x} \mathrm{C}_{60}$ diffraction patterns highlighted the presence of $\mathrm{LiH}$ (see the inset Fig. 4). It is possible to give an estimation of $y$ assuming $\alpha=0$. Another assumption we have made is that the hydrofullerene composition is $\mathrm{C}_{60} \mathrm{H}_{2 n}$, where $n \geq 1$, since only an even number of hydrogen atoms is considered to produce a stable $\mathrm{C}_{60} \mathrm{H}_{y}$ molecule. ${ }^{38}$ In the further discussion, for simplicity, we will also exclude the first absorption process at $140{ }^{\circ} \mathrm{C}$. For $\mathrm{Li}_{6} \mathrm{C}_{60}$ about 20 hydrogen atoms are chemisorbed on $\mathrm{C}_{60}$ at the end of the absorption process at $280{ }^{\circ} \mathrm{C}\left(\sim 2.7 \mathrm{wt} \% \mathrm{H}_{2}\right)$. During the first two dehydrogenation steps at 291 and $324{ }^{\circ} \mathrm{C}$ about $0.28 \mathrm{wt} \% \mathrm{H}_{2}$ per step are released (2 hydrogen atoms per step: $\mathrm{C}_{60} \mathrm{H}_{18}$ and $\mathrm{C}_{60} \mathrm{H}_{16}$ are respectively formed). The third dehydrogenation process, occurring at $380{ }^{\circ} \mathrm{C}$, allows us to desorb $2.1 \mathrm{wt} \% \mathrm{H}_{2}$, corresponding to the remaining hydrogen atoms. Curiously, a peak associated with this desorption was not observed in the DSC of $\mathrm{Li}_{6} \mathrm{C}_{60}$ hydrogenated at $350{ }^{\circ} \mathrm{C}$. For $x=0.5$, the total chemisorbed hydrogen ( $4.7 \mathrm{wt} \%$ ) corresponds to $\mathrm{C}_{60} \mathrm{H}_{38}$. During the following three steps of dehydrogenation at 280,331 , and $350{ }^{\circ} \mathrm{C}, \mathrm{C}_{60} \mathrm{H}_{34}, \mathrm{C}_{60} \mathrm{H}_{24}$, and $\mathrm{C}_{60}$ are respectively formed. When $x=1$, about 36 hydrogen atoms are chemisorbed on fullerene $\left(\mathrm{C}_{60} \mathrm{H}_{36}\right)$ at the end of the absorption process. During the second dehydrogenation process $\left(257{ }^{\circ} \mathrm{C}\right), \mathrm{C}_{60} \mathrm{H}_{36}$ loses about 4 hydrogen atoms per molecule. The third step at $315{ }^{\circ} \mathrm{C}$ brings $\mathrm{C}_{60} \mathrm{H}_{22}$ and the complete dehydrogenation is achieved at $365{ }^{\circ} \mathrm{C}$.

Similar paths of dehydrogenation were found for $x=2-6$, characterized by different weights in $\mathrm{C}_{60}$ hydrogenation for the three steps.

The first stage at around $140{ }^{\circ} \mathrm{C}$ was considered together with the first of the three high temperature processes in the calculation of the dehydrogenation paths, due to the low value of hydrogen involved ( $0-2$ hydrogen atoms per $\mathrm{C}_{60} \mathrm{H}_{y}$, depending on $x$ ). Since this process is very far in temperature (about $100{ }^{\circ} \mathrm{C}$ below) from the other three processes, we attribute it to extrinsic hydrogen species (i.e. hydrogen not bound to carbon). Comparing the four stages of desorption, it is clear that this step only occurs when $\mathrm{Na}$ is intercalated. A possible explanation is that the hydrogen atoms responsible for this process are likely to form a chemical bond with sodium, either in the form of an ion (e.g. sodium hydride), or clustered with intercalated lithium. The second hypothesis is likely to occur when, as previously assumed, ${ }^{39}$ the mechanism of hydrogenation can be explained through a spillover-like effect. In fact, the hydrogen molecule is quickly dissociated by the cluster during the first stage of absorption, until the cluster itself becomes less effective to perform this task. Then, the hydrogenation of fullerene proceeds at a lower rate since the alkali cluster has been partly de-intercalated in the form of hydride. This was already evidenced in Pt-Pd doped $\mathrm{Li}_{6} \mathrm{C}_{60}$, where the presence of a catalyst allowed to continue the fast process at the limit, even when $\mathrm{LiH}$ was segregated. ${ }^{26}$ Anyway, in that case the presence of the catalyst did not significantly influence the desorption enthalpy. In contrast, by substituting Li with small fractions of $\mathrm{Na}$, the absorption process is faster. Apparently, Na, more than $\mathrm{Li}$, is likely to remain intercalated in the hydrofulleride structure affecting the hydrogen dissociation process and the $\mathrm{C}_{60} \mathrm{H}_{y}$ state of charge, thus the $\mathrm{C}-\mathrm{H}$ bond strength and the dehydrogenation enthalpy. This is clearly demonstrated by the absence of $\mathrm{NaH}$ peaks in the XRD profile of $\mathrm{NaLi}_{5} \mathrm{C}_{60}$ (see Fig. 4). Moreover, the ${ }^{23} \mathrm{Na}$ and ${ }^{7} \mathrm{Li}$ NMR study carried out on these samples for $x=0,1,5$, and 6 also evidenced the lowest activation barrier for the diffusion of $\mathrm{Li}$ when $\mathrm{Na}$ is co-intercalated (i.e. $220 \mathrm{meV}$ in $\mathrm{NaLi}_{5} \mathrm{C}_{60}$ and $280 \mathrm{meV}$ in $\mathrm{Li}_{6} \mathrm{C}_{60}$ ) and the blocked dynamics of Na for $x=1 .^{33}$ These results highlight the stabilizing effect of $\mathrm{Na}$ on the fcc structure of $\mathrm{NaLi}_{5} \mathrm{C}_{60}$, which hinders the fcc-to-bcc structural transition (the kinetic limiting process to the hydrogenation of $\mathrm{Li}_{6} \mathrm{C}_{60}{ }^{24}$ ). Eventually, the higher mobility of $\mathrm{Li}$ is also associated with enhanced hydrogen storage kinetics when this ion is directly involved in the chemisorption process. ${ }^{40,41}$

\section{Conclusions}

Mixed alkali-cluster intercalated fullerides $\mathrm{Na}_{x} \mathrm{Li}_{6-x} \mathrm{C}_{60}$ have been synthesized by means of a two step procedure consisting in the thermal decomposition of sodium azide in $\mathrm{C}_{60}$ and the ball-milling of metallic lithium with $\mathrm{Na}_{x} \mathrm{C}_{60}$. The hydrogen storage investigation proved the "catalytic" effect of $\mathrm{Na}$ in promoting the hydrogenation of the $\mathrm{C}_{60}$ anion. On one hand, the weight of hydrogen chemisorbed by $\mathrm{Na}_{0.5} \mathrm{Li}_{5.5} \mathrm{C}_{60}$ and $\mathrm{NaLi}_{5} \mathrm{C}_{60}$ at $280{ }^{\circ} \mathrm{C}$ is improved by a factor of about 75 and $60 \%$, respectively, compared to $\mathrm{Li}_{6} \mathrm{C}_{60}$, with about $70 \%$ better rate of absorption. On the other hand, the DSC coupled manometric measurements evidenced that the dehydrogenation enthalpy is dramatically affected when small quantities of $\mathrm{Li}$ are substituted by Na. In particular, $\Delta H_{\text {des }}=43.8 \mathrm{~kJ} \mathrm{~mol}^{-1} \mathrm{H}_{2}$ for $\mathrm{NaLi}_{5} \mathrm{C}_{60}$, about $17 \mathrm{~kJ} \mathrm{~mol}^{-1}$ less than $\mathrm{Li}_{6} \mathrm{C}_{60}$. This study allowed us to establish that $\mathrm{NaLi}_{5} \mathrm{C}_{60}$ represents the best compromise between the amount of stored hydrogen, kinetics of ab/de-sorption, and enthalpy of dehydrogenation.

\section{Acknowledgements}

This work has received support from the Cariplo foundation (Project number 2013-0592, "Carbon based nanostructures for innovative hydrogen storage systems") and from the European Union's Horizon 2020 research and innovation programme under the Marie Skłodowska-Curie grant agreement no. 665593. We would like to thank Dr Gavin Stenning for help on the WAXS instrument in the Materials Characterisation Laboratory at the ISIS Neutron and Muon Source.

\section{Notes and references}

1 J. Kohanoff, W. Andreoni and M. Parrinello, Chem. Phys. Lett., 1992, 198, 472-477.

2 K. R. S. Chandrakumar and S. K. Ghosh, Nano Lett., 2008, 8, 13-19. 
3 Q. Sun, P. Jena, Q. Wang and M. Marquez, J. Am. Chem. Soc., 2006, 128, 9741-9745.

4 M. Yoon, S. Yang, C. Hicke, E. Wang, D. Geohegan and Z. Zhang, Phys. Rev. Lett., 2008, 100, 206806.

5 T. Yildirim, O. Zhou, J. E. Fischer, N. Bykovetz, R. A. Strongin, M. A. Cichy, A. B. Smith III, C. L. Lin and R. Jelinek, Nature, 1992, 360, 568-571.

6 F. Giglio, D. Pontiroli, M. Gaboardi, M. Aramini, C. Cavallari, M. Brunelli, P. Galinetto, C. Milanese and M. Riccò, Chem. Phys. Lett., 2014, 609, 155-160.

7 M. Aramini, M. Gaboardi, G. Vlahopoulou, D. Pontiroli, C. Cavallari, C. Milanese and M. Riccò, Carbon, 2014, 67, 92-97.

8 M. Gaboardi, C. Cavallari, G. Magnani, D. Pontiroli, S. Rols and M. Riccò, Carbon, 2015, 90, 130-137.

9 M. Tomaselli, B. H. Meier, M. Riccò, T. Shiroka and A. Sartori, J. Chem. Phys., 2001, 115, 472.

10 M. J. Rosseinsky, D. W. Murphy, R. M. Fleming, R. Tycko, A. P. Ramirez, G. Dabbagh and S. E. Barrett, Nature, 1992, 356, 416-418.

11 L. Cristofolini, M. Riccò and R. De Renzi, Phys. Rev. B: Condens. Matter Mater. Phys., 1999, 59, 8343-8346.

12 J. A. Teprovich, M. S. Wellons, R. Lascola, S.-J. Hwang, P. A. Ward, R. N. Compton and R. Zidan, Nano Lett., 2012, 12, 582-589.

13 P. Mauron, A. Remhof, A. Bliersbach, A. Borgschulte, A. Züttel, D. Sheptyakov, M. Gaboardi, M. Choucair, D. Pontiroli, M. Aramini, A. Gorreri and M. Riccò, Int. J. Hydrogen Energy, 2012, 37, 14307-14314.

14 P. Mauron, M. Gaboardi, A. Remhof, A. Bliersbach, D. Sheptyakov, M. Aramini, G. Vlahopoulou, F. Giglio, D. Pontiroli, M. Riccò and A. Züttel, J. Phys. Chem. C, 2013, 117, 22598-22602.

15 A. Yoshida, T. Okuyama, T. Terada and S. Naito, J. Mater. Chem., 2011, 21, 9480.

16 J. A. Teprovich, A. L. Washington, J. Dixon, P. A. Ward, J. H. Christian, B. Peters, J. Zhou, S. Giri, D. N. Sharp, J. A. Velten, R. N. Compton, P. Jena and R. Zidan, Nanoscale, 2016, 18760-18770.

17 E. Callini, S. Kato, P. Mauron and A. Züttel, Chim. Int. J. Chem., 2015, 69, 269-273.

18 P. A. Ward, J. A. Teprovich, R. N. Compton, V. Schwartz, G. M. Veith and R. Zidan, Int. J. Hydrogen Energy, 2015, 40, 2710-2716.

19 P. A. Ward, J. A. Teprovich, B. Peters, J. Wheeler, R. N. Compton and R. Zidan, J. Phys. Chem. C, 2013, 117, 22569-22575.

20 A. Paolone, F. Vico, F. Teocoli, S. Sanna, O. Palumbo, R. Cantelli, D. A. Knight, J. A. Teprovich and R. Zidan, J. Phys. Chem. C, 2012, 116, 16365-16370.
21 A. Paolone, O. Palumbo, F. Leardini, R. Cantelli, D. A. Knight, J. A. Teprovich and R. Zidan, J. Alloys Compd., 2013, 580, S67-S69.

22 D. T. Shane, R. L. Corey, L. H. Rayhel, M. Wellons, J. A. Teprovich, R. Zidan, S. Hwang, R. C. Bowman and M. S. Conradi, J. Phys. Chem. C, 2010, 114, 19862-19866.

23 P. Mauron, M. Gaboardi, D. Pontiroli, A. Remhof, M. Riccò and A. Züttel, J. Phys. Chem. C, 2015, 119, 1714-1719.

24 M. Gaboardi, S. Duyker, C. Milanese, G. Magnani, V. K. Peterson, D. Pontiroli, N. Sharma and M. Riccò, J. Phys. Chem. C, 2015, 119, 19715-19721.

25 D. A. Knight, J. A. Teprovich, A. Summers, B. Peters, P. A. Ward, R. N. Compton and R. Zidan, Nanotechnology, 2013, 24, 455601.

26 M. Aramini, C. Milanese, D. Pontiroli, M. Gaboardi, A. Girella, G. Bertoni and M. Riccò, Int. J. Hydrogen Energy, 2014, 39, 2124-2131.

27 J. A. Teprovich, D. A. Knight, B. Peters and R. Zidan, J. Alloys Compd., 2013, 580, S364-S367.

28 A. A. EL-Barbary, Int. J. Hydrogen Energy, 2016, 41, 375-383. 29 Q. Wang and P. Jena, J. Phys. Chem. Lett., 2012, 3, 1084-1088. 30 M. Kobayashi, N. Kimata and S. Heguri, J. Phys. Chem. Solids, 2010, 71, 689-691.

31 Y. Kubozono, Y. Takabayashi, T. Kambe, S. Fujiki, S. Kashino and S. Emura, Phys. Rev. B: Condens. Matter Mater. Phys., 2001, 63, 45418.

32 R. Céolin, J. Ll.Tamarit, D. O. López, M. Barrio, V. Agafonov, H. Allouchi, F. Moussa and H. Szwarc, Chem. Phys. Lett., 1999, 314, 21-26.

33 N. Sarzi Amadè, D. Pontiroli, L. Maidich, M. Ricco, M. Gaboardi, G. Magnani, P. Carretta and S. Sanna, J. Phys. Chem. C, 2017, 121, 6554-6560.

34 B. I. Dunlap, D. W. Brenner, J. W. Mintmire, R. C. Mowrey and C. T. White, J. Phys. Chem., 1991, 95, 5763-5768.

35 L. E. Hall, D. R. McKenzie, M. I. Attalla, A. M. Vassallo, R. L. Davis, J. B. Dunlop and D. J. H. Cockayne, J. Phys. Chem., 1993, 97, 5741-5744.

36 B. I. Dunlap, D. W. Brenner and G. W. Schriver, J. Phys. Chem., 1994, 98, 1756-1757.

37 L. E. Hall, D. R. McKenzie, R. L. Davis, M. I. Attalla and A. M. Vassallo, Acta Crystallogr., Sect. B: Struct. Sci., 1998, 54, 345-350.

38 P. A. Cahill, The Chemistry of Fullerenes, 1995, pp. 53-66.

39 M. Aramini, M. Gaboardi, G. Vlahopoulou, D. Pontiroli, C. Cavallari, C. Milanese and M. Riccò, Carbon, 2013, 1-2. 40 H. Wu, J. Am. Chem. Soc., 2008, 130, 6515-6522.

41 W. I. F. David, M. O. Jones, D. H. Gregory, C. M. Jewell, S. R. Johnson, A. Walton and P. P. Edwards, J. Am. Chem. Soc., 2007, 129, 1594-1601. 